\title{
The effect of Vitamin C supplementation toward high sensitivity c-reactive protein (hsC-RP) level on male adolescent obesity in Padang
}

\author{
Nedi Hidayat, Eka Agustia Rini, Rizanda Machmud \\ From 7th APPES Biennial Scientific Meeting \\ Nusa Dua, Bali. 14-17 November 2012
}

\section{Background}

Prevalence of obesity in children and adolescent has significantly increased, it becomes a serious problem because of the over- releasing of interleukin-6 (IL-6), disruption on the oxidative balance, risk factor of getting cardiovascular disease with typically marked by elevation of the hight sensitivity C-Reactive Protein (hsC-RP). On the way to decrease IL-6 release from the visceral adipose cell is by treating the oxidative stress with antioxidant agent, such as Vitamin C.

\section{Objective}

To examine mean hsC-RP level on male adolescent obesity in Padang and to know the effect of Vitamin C supplementation toward hsC-RP level on male adolescent obesity in Padang.

\section{Method}

This is an experimental double blind study with 40 samples on March until May 2011, which were divided into 2 groups. One group consumed Vitamin C $500 \mathrm{mg}$ and another group consumed placebo, both twice a day for 8 weeks. The hsC-RP level is measured before and after drug consumptions. The data were analyzed with chisquare and general liniear model repeated measure, the confidence interval, $\mathrm{p}<0.05$.

\section{Result}

The mean of initial hsC-RP level is higher in the Vitamin $C$ group than the placebo group $((2.28 \pm 1.51$ vs $1.78 \pm 1.23 \mathrm{mg} / \mathrm{L})$. At the end of the study, mean hsC-RP level were decreasing in both groups $(1.09 \pm 1.13$ vs

Endocrinology Division, Pediatric Health Departement of Medical Faculty Andalas University, Dr. M. Djamil Hospital Padang
$0.89 \pm 1.09 \mathrm{mg} / \mathrm{L})$. The changing in hsC-RP level after 8 weeks isn't significant statistically $(\mathrm{p}=0.481)$.

\section{Conclusion}

The mean hsC-RP level is high and Vitamin C supplementation was not significantly decreasing hsC-RP level on male adolescent obesity in Padang.

Published: 3 October 2013

\section{doi:10.1186/1687-9856-2013-S1-P85}

Cite this article as: Hidayat et al:: The effect of Vitamin $C$

supplementation toward high sensitivity c-reactive protein (hsC-RP) level on male adolescent obesity in Padang. International Journal of Pediatric Endocrinology 2013 2013(Suppl 1):P85.
Submit your next manuscript to BioMed Central and take full advantage of:

- Convenient online submission

- Thorough peer review

- No space constraints or color figure charges

- Immediate publication on acceptance

- Inclusion in PubMed, CAS, Scopus and Google Scholar

- Research which is freely available for redistribution

\section{( Biomed Central}

